\title{
SOCIALDEMOKRATIJOS SAMPRATA
}

TARPUKARIO LSDP PROGRAMINIUOSE

DOKUMENTUOSE BEI PARTIJOS

LYDERIO STEPONO KAIRIO

\section{TEKSTUOSE}

\author{
Dr. Gintaras Mitrulevičius
}

El.paštasmitrgint@gmail.com

\section{Santrauka}

Straipsnyje nagrinejama vienos iš tarpukario Lietuvos Respublikos parlamentinio laikotarpio pagrindiniu partiju - Lietuvos socialdemokratu partijos (LSDP) ideologijai būdinga socialdemokratijos samprata. Pagrindinis straipsnio objektas - LSDP programos bei ịvairūs partijos lyderio ir ideologo Stepono Kairio tekstai. Svarbiausias nagrinejamas aspektas - Lietuvos socialdemokratu ideologine savivoka kaip LSDP programiniuose dokumentuose ir partijos lyderio tekstuose atsakoma i klausimus, kas yra socialdemokratai ir socialdemokratu partija. Taip pat nagrinejama, kas lemè, kad socialdemokraty ideologine savivoka buvo tokia, kokia ji atskleista šiame straipsnyje. Nagrinejamu tekstu analizé akivaizdžiai patvirtina teigini, kad to meto Lietuvos, kaip ir daugelio kitǔ šaliu, socialdemokratai save suvoke kaip socialistine, marksistine visuomenès raidos analize besivadovaujančią darbininkų klasès partiją, siekiančia sukurti socializma kaip santvarka. Straipsnyje rekonstruota tarpukario LSDP socialdemokratijos samprata aiškiai paneigia sovietinio komunizmo ideologijos ir istoriografijos teiginius, kad tarpukario socialdemokratija „išdave 
marksizma", atsisakè siekti socializmo santvarkos, nustojo büti darbininku klasés partija.

Reikšminiai žodžiai: socialdemokratų partija, LSDP, socialdemokratija, socializmas, demokratinis socializmas, partijų ideologinė savivoka, Steponas Kairys.

\section{İvadas: žvilgsnio ị istorinès socialdemokratijos sampratą aktualumas}

Nuo XIX a. pabaigos daugelyje Europos šalių tuo metu ịsikūrusios socialdemokratų partijos nepaliaujamai didino politinę ịtaką visuomenei, o šalyse, kur vyko parlamentų rinkimai, labai sparčiai augo socialdemokratų rinkèjų bei parlamentų frakcijų narių ${ }^{1}$. Nors Pirmojo pasaulinio karo metais socialdemokratiją ištiko idejjinè-politinè bei organizacinè krizè, kuri tęsèsi ir pirmaisiais pokario metais bei rimtą iššūkị jai metė rusiškasis bolševizmas, jo pergale Rusijoje bei tarptautinio komunistinio judèjimo atsiradimas, tačiau daugelyje šalių socialdemokratija išlaikè didelę ịtaką darbininkų klasei ir kurị laiką toliau didino politinę įtaką, nors ilgainiui, vienur anksčiau, kitur vèliau, daugelyje šalių susidūrusi su fašizmo (nacizmo) bei dešiniųjų autoritarinių režimų įsigalèjimu, patyrẻ rimtų politinių pralaimèjimų.

$\mathrm{XX}$ a., ypač antroje pusėje, socialdemokratija suvaidino svarbų vaidmenį kuriant socialines gerovès valstybes Vakarų Europos šalyse. Anot istorikų, politologų ir kitų tyrinètojų, nors socialistai-socialdemokratai ne vieninteliai kūrè ir igyvendino socialinę gerovès valstybę („Welfare State"), tačiau pirmiausiai būtent jų pastangomis atsirado ir iškilo („gerovès valstybės“) institutai, leidę iš esmès pagerinti

1 Žr.: Гуревич, П. Парламентские выборы и рост соид.-дем. Партий.-1906; Sassoon, D. One Hundread of Socialism. The West European Left in the Twentieth Century. New York, 1996; Bartolini, S. The Political Mobilization of the European Left 1860-1980. Cambridge, 2000. 
¿̇vairių visuomenès sluoksnių padètị, ir būtent jie „vaidino motoro ir šturvalo vaidmeni vystymosi link socialinès valstybės procese ${ }^{\text {“2 }}$. Ne veltui socialdemokratijos vaidmenị turèjo pripažinti net ideologiniai oponentai. Pavyzdžiui, garsus sociologas liberalas Ralfas Dahrendorfas socialdemokratiją pavadino „dominuojančia XX a. politine jèga“, o pati XX a. „socialdemokratijos amžiumi“3. Be abejo, čia buvo kalbama apie Vakarų Europą. Toks socialdemokratijos vaidmuo šiame regione XX a. - pakankamas argumentas kelti klausimą, kas yra socialdemokratų partijos, ir kaip i jị ỉvairiu laikotarpiu atsakẻ patys socialdemokratai.

Tiesa, Lietuvoje dèl XX a. istorijos aplinkybių socialdemokratija neatliko tokio vaidmens kaip Vakarų šalyse. Kita vertus, Lietuvoje ji buvo labai svarbi nacionalinio išsivadavimo judejimo (ypač per 1905 m. tautinę revoliuciją) bei Lietuvos valstybingumo (at)kūrimo procesams, nepaisant to, kad (at)kuriant šalies valstybingumą socialdemokratija patyrė idejjinę, politinę ir organizacinę diferenciaciją ir dèl to ịvykusị (kaip ir daugelio kitų šalių socialdemokratų partijų) radikalaus kairuoliško sparno atskilimą; tai lėmé Lietuvos komunistų partijos atsiradimą 4 .

Tarpukario Lietuvos Respublikos demokratiniu laikotarpiu socialdemokratų partija (LSDP) tiek būdama opozicijoje (didžiąją minèto

2 Европейская социал- демократия накануне XXI столетия. Отв. ред. Б. С. Орлов. Москва, 1998, с. 130.

Dahrendorf, R. Apmąstymai apie Revoliuciją Europoje. Vilnius, 1990, p. 44.

4 Plačiau apie tai žr.: Mitrulevičius, G. Lietuvos socialdemokratijos ideologinè-politinè raida 1914-1919 metais. Istoriografija, tarptautinis ir istorinis kontekstai, santykis su Lietuvos valstybingumo kūrimu. Vilnius, 2017; Sabaliūnas, L. Lithuanian Social Democracy in perspective 1893-1914. Durham and London, 1990; Vilčinskas, J. Lietuvos socialdemokratija kovoje dèl krašto nepriklausomybès. Istoriné apžvalga. London, 1985. Glaustai žr.: Mitrulevičius, G. Lietuvos socialdemokratai iki Steigiamojo Seimo, Socialdemokratai Lietuvos Respublikos Seimuose. Vilnius, 2006, p. 17-61; Mitrulevičius, G. Social Democracy in the Formation of the Modern Lithuanian State. Social Democracy and State Foundation. The emergence of a new European state landscape after the First World War. Bonn, 2019, p. 109-131. 
trumpo laikotarpio dalį), tiek pozicijoje vaidino svarbų vaidmenị šalies demokratizacijos procese ${ }^{5}$. Deja, šis procesas buvo nutrauktas $1926 \mathrm{~m}$. gruodžio $17 \mathrm{~d}$. valstybinio perversmo, po kurio opozicinių režimui politinių partijų, tarp jų ir LSDP (net šiek tiek daugiau negu kitų partijų) politinè veikla buvo ribojama ir varžoma, o vèliau ir visai uždrausta ${ }^{6}$.

Žinoma, sovietinio totalitarinio režimo metais apie legalią ir apskritai bet kokią socialdemokratų veiklą negalèjo būti nẻ kalbos. Lietuviška socialdemokratinè politinè mintis bei socialdemokratinio judejimo apraiškos tebuvo galimos emigracijoje ${ }^{7}$.

Žvilgtelèję ị Lietuvos socialdemokratijos istoriją, galime teigti, kad LSDP vaidmuo lietuvių nacionalinio išsivadavimo judejjimo bei Lietuvos valstybingumo (at)kūrimo procesams, taip pat buvimas viena iš pagrindinių tarpukario Lietuvos parlamentinio laikotarpio (19201926 m.) partijų suteikia pakankamai argumentų kelti klausimą, kas gi yra socialdemokratų partija pačios istorinès LSDP, jos programų bei lyderių ir ideologų požiūriu.

Kitas motyvas (proginis) kelti ši klausimą yra šiemet minimas Steigiamojo Seimo 100-metis - šio Seimo veikloje aktyviai dalyvavo Lietuvos socialdemokratų partijos frakcija.

Dar vienas svarbus proginis motyvas ši klausimą nagrinèti būtent tokiu aspektu, koks ịvardintas straipsnio pavadinime ir objekto bei

5 Žr.: Mitrulevičius, G. Radikaliai demokratinès respublikos vizija: Steigiamojo Seimo socialdemokratų frakcijos nuostatos priimant $1920 \mathrm{~m}$. laikinają ir $1922 \mathrm{~m}$. nuolatinę Lietuvos Respublikos Konstitucijas. Socialiniu mokslu studijos. Vilnius, 2014, Nr. 6 (3 ), p. 706-740; Mitrulevičius, G. Socialdemokratu santykis su Lietuvos Respublikos demokratizacijos procesu Steigiamojo Seimo darbo metu 1920-1922 m., Parlamento studijos, Nr. 9, 2010, p. 79-124; Mitrulevičius, G. Socialdemokratai Lietuvos Respublikos Seimuose 1920-1927, Socialdemokratai Lietuvos Respublikos Seimuose. Vilnius, 2006, p. 63-102.

6 Žr.: Astramskas, A. Gaigalaitè, A. Lietuvos socialdemokratų partijos opozicija tautininkams, Lietuvos istorijos metraštis, 1990. Vilnius, 1992, p. 61-76; Mitrulevičius, G. Lietuvos socialdemokratai po III Seimo paleidimo, Socialdemokratai Lietuvos Respublikos Seimuose. Vilnius, 2006, p. 201-221.

7 Žr.: Vilčinskas, J. Min. veik., p. 251-332. 
tikslo formuluotėse, - 2019 m. sausio pradžioje suejo 140 metų nuo ilgamečio istorinès LSDP lyderio, vieno ryškiausių XX a. pirmųjų dviejų trečdalių lietuvių politikų ${ }^{8}$ Stepono Kairio gimimo (2019 m. gruodị suejo 55 metai nuo jo mirties).

S. Kairys buvo ne tik $1918 \mathrm{~m}$. Vasario 16-osios Akto signataras ir vienas iš pagrindinių jo autorių bei apskritai vienas iš ryškiausių lietuvių nacionalinio judejjimo veikèjų XX a. pradžioje bei Lietuvos valstybingumo (at)kūrimo procese $1916-1919$ m. ${ }^{9}$, taip pat talentingas inžinierius praktikas bei žymus specializuotų inžinerijos dalykų dėstytojas, Vytauto Didžiojo universiteto profesorius ${ }^{10}$. Kaip jau užsiminėme, jis buvo ilgametis istorinès LSDP politinis lyderis bei pagrindinis istorinès lietuviškosios socialdemokratijos ideologijos formuotojas bei apskritai vadintinas garsiausiu istoriniu Lietuvos socialdemokratu. Kaip 2002 m. pristatant Gedimino Ilgūno monografiją apie S. Kairị, perfrazuodamas vieną garsią sovietinių laikų frazę, pabrèžè istorikas Liudas Truska (turbūt tikrai ne pirmas): „Kai kalbame apie Steponą Kairị, turime mintyje Lietuvos socialdemokratiją, o kai kalbame apie Lietuvos socialdemokratiją, turime mintyje Steponą Kairï“.

8 Žr.: Ilgūnas, G. Steponas Kairys. Vilnius, 2002; Ilgūnas, G. Kairys Steponas, Socialdemokratai Lietuvos Respublikos Seimuose, Vilnius, 2006, p. 136-140; Ilgūnas, G. Steponas Kairys, Lietuvos Steigiamojo Seimo (1920-1922 metu) nariu biografinis žodynas (sud. A. Ragauskas, M. Tamošaitis). Vilnius, 2006, p. 179-182.

9 Žr. Mitrulevičius, G. Už nepriklausomą, demokratinę ir teisingą Lietuvą: Vasario 16-osios Akto signataro Stepono Kairio visuomeninės-politinės veiklos bruožai. I dalis. Gimtasai kraštas 16. 2019, 1, p. 19-27; Mitrulevičius, G. Socialdemokratai Steponas Kairys ir Mykolas Biržiška Lietuvos Tarybos darbe: santykis su Vasario 16-osios Akto prièmimu. Parlamento studijos, Nr. 11, 2011, p. 62-104; Selenis, V. Steponas Kairys ir Vasario 16-oji, Nepriklausomybès sqsiuviniai, 2019, 2 (28), p. 3-09; Kirvelis, D. Stepono Kairio, Vasario 16-osios Akto signataro Lietuvos valstybès vizija. Vilnius, 2018; Vireliūnaitè, L. S. Kairys - maištininkas, be kurio Nepriklausomybès Aktas būtų atrodęs kitaip. Prieiga per internetą: //https:// www. $15 \mathrm{~min} .1 \mathrm{t} / \mathrm{media}-$ pasakojimai/signatarai-kairys-244.

10 Žr. Stražnickas, J. Žygis: Steponas Kairys - inžinierius, mokslininkas, kūrëjas. Kaunas, 1999. 
S. Kairys buvo vienas iš pagrindinių daugelio istorinès LSDP konferencijų, suvažiavimų rezoliucijų, nutarimų, atsišaukimų, LSDP programų, taip pat įvairiuose lietuvių socialdemokratų laikraščiuose publikuotų ideologinių ir teorinių ideologinių straipsnių autorius. Per ilgą savo kaip istorinès lietuviškos socialdemokratijos lyderio ir ideologo kelią S. Kairys yra parašęs ne vieną tekstą, skirtą socialdemokratijos programinès-ideologinès raidos klausimams, ne vieną straipsnị, skirtą išsiaiškinti, kas yra socialdemokratija, apskritai socializmas, koks bolševizmo santykis su socializmu ir t. t. ${ }^{11}$. Vis dèlto, nors S. Kairio ilgametès daugialypès visuomeninès, politinès bei profesinès veiklos aspektai ir ypač vaidmuo Lietuvos valstybingumo kūrimo procesui yra susilaukę nemažai ịvairių autorių dėmesio ${ }^{12}$, tačiau jo kaip LSDP ideologo, ryškiausio lietuviškos socialdemokratinès minties reiškèjo, veiklai dèmesio tikrai trūksta.

Reikia pasakyti, kad apskritai Lietuvoje istorinès LSDP ideologinè tradicija dar nepakankamai žinoma ir aktualizuota. Matyt, galime teigti, kad teorinių, ideologinių, programinių S. Kairio tekstų apie socialdemokratiją neprisiminimas ir neaktualizavimas laikytinas viena (šalia kitų) priežasčių, dèl kurių kyla tam tikrų ideologinès savivokos, ideologinès tapatybės bei praktinès politikos santykio su socialdemokratijos ideologine-politine tradicija problemų; šios problemos, anot ịvairių tyrinètojų bei apžvalgininkų, yra būdingos nemažai daliai dabartinių Lietuvos socialdemokratų ${ }^{13}$.

${ }_{11}$ Žr. pvz.: Mitrulevičius, G. Steponas Kairys apie socializmo ir bolševizmo santykị. Gairès, 2012, Nr. 9, p. 36-39, Nr. 10, p. 40-44.

12 Žr.: Ilgūnas, G. Steponas Kairys. Vilnius, 2002, p. 423, 428-430; Literatūra apie Steponą Kairi // http://senas.lnb.lt/lnb/selectPage.do?docLocator=194AA8F5A73 311E2A197746164617373\&inlanguage $=1 \mathrm{t}$

${ }^{13}$ Pagrịsti și teiginị galima nuorodomis ị daugybę tekstų. Žr. pvz. keletą jų: Ramonaite, A., Jokubaitis, A., Kavaliauskaite, J., Morkevičius, V., Vinogradnaitė, I., Žiliukaitė, R. Partinès demokratijos pabaiga? Politinis atstovavimas ir ideologijos. Vilnius, 2009, p. 34-35, 39, 51, 53; Demokratija be darbo judejimo ? (sud. A. Bielskis). Vilnius, 2009, p. 13, 58, 131; Laurėnas, V. Spartèjančios visuomenés politinis režimas. Lietuvos politinès sociologijos studija. Klaipéda, 2017, p. 265, 269-270, 272-273, 340. 
Kaip žinoma, Lietuvoje natūrali socialdemokratinio judejjimo ideologiné-politinè raida buvo prievarta nutraukta stalinistinei SSRS okupavus Lietuvą ir ịvedus totalitarinị režimą. Dẻl to kelis dešimtmečius trukęs socialdemokratinio judejjimo Lietuvoje pertrūkis ir kiti iš sovietinio komunistinio totalitarizmo kylantys veiksniai iš dalies (šalia kitų - globalių) lèmè itin rimtas pokomunistinès socialdemokratijos ideologinès tapatybės problemas, pačios sąvokos supratimo transformaciją ir paties socialdemokratijos reiškinio mutaciją. Viena iš tai lemusių priežasčių, išplaukusių iš minèto socialdemokratinio judejjimo raidos pertrūkio ir komunistinio režimo pasekmių, yra menkos, fragmentiškos, eklektiškos, o kartais tiesiog iškreiptos sovietinių vadinamųjų visuomeninių mokslų „deformuotos“ žinios apie socialdemokratijos istorinę tradiciją ir istoriją.

Kita vertus, anot tyrinėtojų, šiandieninès ideologijos ir ypač praktikos santykis su istorine ideologine-politine tradicija problemiškas ir kitų pokomunistinių šalių socialdemokratų partijoms ${ }^{14}$ ir net socialdemokratijai apskritai, taigi ir Vakarų šalių socialdemokratų partijoms ${ }^{15}$. Ne veltui jau keletą dešimtmečių vis kalbama ne tik apie socialdemokratijos krizę, bet ir apie jos „pabaigą“, „galą“ ar net ir „mirtį “16. Vienas

${ }_{14}$ Žr.: pvz: Даудерштадт, М., Герритис, А., Маркус, Г. Г. Трудная трансформация сочиал-демократии в странах Центральной и Восточной Европы. Москва, 2001, c. 122-151.

${ }^{15}$ Apie tai yra labai daug ịvairaus žanro tekstų ịvairiomis kalbomis. Apibendrintai ir labai glaustai žr.: Mitrulevičius, G. Ar socialdemokratai siekia igyvendinti demokratini socializmą? Apie socialdemokratinès socializmo sampratos aktualizavimo poreikị. Gairès, 2012, Nr. 1, p. 32-37.

${ }^{16}$ Žr. tik keletą iš daugelio darbų su itin charakteringais pavadinimais: Scharpf, F.W. Crisis and Choice in European Social Democracy-London, 1991.; Lemke, C., Marks, G. (eds.) The Crisis of Socialism in Europe. Durham, 1992.; Gray, J. After social-democracy-Politics, Capitalism and Common Life, London, 1996; Hamilton, C. What's left? The death of social-democracy, Melbourne: Black Inc., 2006; Lavelle, A. The Death of Social Democracy Political Consequences in the 21st Century, 2008.; The Crisis of Social Democracy in Europe. Edinburg, 2015; Press. What's Left: The Death of Social Democracy: Quarterly Essay 21 Paperback - June 20, 2018 
iš atsakymų, kodèl taip yra, - itin stipriai pakitusi šiandienių socialdemokratų ideologinè savivoka.

Tai rodo, kad ne tik pravartu, įdomu, bet ir svarbu pažvelgti $\mathfrak{i}$ istorinių socialdemokratų ideologinę savivoką, taigi ir $\mathfrak{i}$ tai, kaip ji atspindima istorinès LSDP programose bei istorinių Lietuvos socialdemokratų, pirmiausia jų lyderio ir pagrindinio ideologo S. Kairio, politinès minties (kaip, beje, ir visos istorinès LSDP ideologinès-politinès tradicijos) palikime. Tai būtų proga prisiminti socialdemokratijos kaip ideologinio-politinio reiškinio prigimtinę esmę, šiandien daugelio socialdemokratų, deja, atrodo, primirštą ar apskritai nežinomą, kaip, beje, atrodo, ir ne vienam autoriui, rašančiam apie šiuolaikinès socialdemokratijos problematiką.

Tad šiame straipsnyje aiškinsimès vieną LSDP ideologinès-politinès tradicijos aspektų - kaip tarpukariu (su vienu kitu ekskursu i laikotarpi iki Pirmojo pasaulinio karo) šios partijos programiniuose dokumentuose, kurių pagrindinis autorius, kaip minèta, buvo S. Kairys, bei jo paties ideologiniuose programiniuose tekstuose buvo atsakoma į esminius ideologinès savivokos klausimus: kas yra socialdemokratai, kas yra socialdemokratų partija. Taip pat čia aiškinsimės, kas lèmé, kad tie straipsnyje būsiantys atskleisti atsakymai buvo būtent tokie. İ kitus aspektus atkreipsime dèmesị tik tiek, kiek tai būtina tam tikriems konteksto paaiškinimams.

Taigi šio straipsnio objektas yra vienas iš tarpukario Lietuvos socialdemokratijos politinès minties arba to meto LSDP ideologijos aspektų, galima sakyti, esminis - partijos ideologinès savivokos aspektas. Straipsnio tikslas yra išsiaiškinti ir rekonstruoti, kaip (ir kodèl) tarpukario LSDP programiniuose dokumentuose bei pagrindinio jų autoriaus partijos lyderio ir ideologo S. Kairio tekstuose atsakoma i klausimus, kas yra socialdemokratai ir socialdemokratų partija. Dèl ribotos apimties nenagrinejjama, kaip ì šiuos klausimus buvo atsakoma po Antrojo pasaulinio karo - tai jau kitas istorinès LSDP raidos ir jos lyderio S. Kairio veiklos etapas. Tai būtų jau kito straipsnio objektas. 
Sovietineje komunistinèje istoriografijoje socialdemokratijos ideologijai buvo skiriama gana daug dèmesio, tačiau iš tiesų dažniausiai kalbėta apie komunistų partijos kovą su socialdemokratais, jų ideologiją labai dažnai vaizduojant iškreiptai, tendencingai, itin sovietiškai komunistiškai ideologizuotai ir supaprastintai ${ }^{17}$.

Nesovietineje istoriografijoje nemažai tarpukario Lietuvos socialdemokratų ideologijos aspektų - ideologinès-politinès nuostatos valstybès konstitucinè-politinès santvarkos, demokratijos, bolševizmo, žemès reformos atžvilgiu, $1931 \mathrm{~m}$. partijos programos nuostatos, šiek tiek ir 1921 m. „Veikimo programa“ yra sulaukę tyrinètojų dèmesio ${ }^{18}$, tačiau šiame straipsnyje nagrinejjamas LSDP ideologijos - socialdemokratų ideologinès savivokos aspektas lietuviškoje mokslinejje literatūroje iki šiol specialiai nebuvo nagrinètas (tik šio straipsnio autorius yra ne moksliniame leidinyje publikavęs šiai problematikai skirtą gerokai trumpesnị ir populiaresnị, mažiau akademinị tekstą ${ }^{19}$ ).

Rengiant straipsni naudotasi tradiciniu istoriniu bei istorinių šaltinių - dokumentų analizès metodais taikant hermeneutinę tyrinejjimo strategiją, kuri „remiasi didelę reikšmę turinčiais šaltiniais, kuriuose atsispindi buvusios žmogaus veiklos apibrèžtumas ir veikèjų savivoka"20. Rašant ši straipsnị remtasi tokiais istoriniais šaltiniais kaip socialdemokratų spauda, LSDP programos, kiti ịvairūs publikuoti ir nepublikuoti dokumentai.

17 Apie sovietinę socialdemokratijos istoriografiją žr.: Mitrulevičius, G. Lietuvos socialdemokratijos ideologiné-politinè raida 1914-1919 metais... p. 54-138.

18 Žr. šio straipsnio 5 išnašą. Taip pat žr.: Krivickas, V. The programs of the Lithuanian Social democratic party 1896-1931. Journal of Baltic Studies. 1980. Vol. XI. P. 99-111; Lukoševičius, V. Liberalizmo raida Lietuvoje. Vilnius, 1995, p. 225-267; Surblys, A. Socialdemokratų ir liaudininkų veikla bei idejjos tarpukario Lietuvoje (1918-1940 m.) ir jų aktualumas šiandien. Prieiga per internetą: // http://knyga.kvb. 1t/uploads/files/studija.doc failo html kopija.; Mitrulevičius, G. Lietuvos socialdemokratų požiūris ị rusiškajị komunizmą 1919-1922 metais, Gairès, 2006, Nr. 5, p. 31-36; Nr. 6, p. 25-31.

19 Žr.: http://www.lsds.lt/lt/pages,id.98?PHPSESSID=c8bcfbc085f1bf9c7563883806 cdcf71. http://www.seti.lt/wp-content/uploads/2011/07/Kas-yra-SDP-S1.pdf

${ }^{20}$ Rüsen, J. Istorika. Vilnius, 2007, p. 128 


\section{„Kas yra socialdemokratai ir ko jie nori?“}

1920 m. balandžio 17 d. „Socialdemokrato“ numeryje (pirmajame atnaujinus leidybą po uždraudimo $1919 \mathrm{~m}$. gruodi) pradètas publikuoti per kelis numerius paskelbtas ideologinio pobūdžio straipsnis „Kas yra socialdemokratai ir ko jie nori?"21 Jo autoriumi laikomas S. Kairys ${ }^{22}$. Šiame straipsnyje išdèstyta socialdemokratijos samprata, būdinga to meto LSDP, kaip ir apskritai nemažai daliai kitų šalių socialdemokratų.

Iš pradžių šiame straipsnyje gana plačiai iš klasikinio marksizmo pozicijų apibūdinama visuomenès socialinè struktūra, kapitalo ir darbo, kapitalistų ir darbininkų santykiai, dèstomos tipiškos marksistinès darbininkų eksploatacijos, pridedamosios darbo vertès teorijos, visuomenès socializacijos bei kapitalizmo kaip „paskutiniosios išnaudotojiškos, eksploatatoriškosios visuomeninès-ekonominès formacijos teorijos" koncepcijos ${ }^{23}$.

Straipsnyje akcentuojamas „Karlo Markso nuopelnas ... kad jis surado mūsų dabartinèj bjaurioj tvarkoj geresnès ateities diegus, kad jis parodè, kaip pats gyvenimas, kaip patys žmonijos ūkio reikalai veda ją neišvengiamai socialistinėn tvarkon “24. Toliau dėstomos klasikinès marksistinès kapitalo ir pramonės koncentracijos, visuomenės proletarizacijos, proletariato istorinès misijos, istorinio vaidmens pereinant iš kapitalizmo ị socializmą koncepcijos bei marksistiné, tiesa,

${ }^{21}$ [Kairys S. ?] Kas yra socialdemokratai ir ko jie nori? Socialdemokratas. 1920, balandžio 17 , Nr. 1, p. 2; 1920, balandžio 24, Nr. 2, p. 2.; 1920, balandžio 29, Nr. 3 , p. $3 ; 1920$, gegužès 6 , Nr. 4 , p. 2-4.

${ }^{22}$ Taip mano S. Kairio biografas G. Ilgūnas. Žr.: Ilgūnas, G. Steponas Kairys, Vilnius, 2002, p. 312.

${ }^{23}$ [Kairys S. ?] Kas yra socialdemokratai ir ko jie nori? Socialdemokratas. 1920, balandžio 17 , Nr. 1, p. 2., 1920, balandžio 24, Nr. 2, p. 2., 1920, balandžio 29, Nr. 3 , p. 3., 1920, gegužès 6, Nr. 4, p. 2-4.

${ }^{24}$ [Kairys S. ?] Kas yra socialdemokratai ir ko jie nori? Socialdemokratas.1920, gegužès 6 , Nr. 4, p. 3 . 
ne pačių Markso ir Engelso, bet jų pasekejjų sukurta ir skirtingai plètojama bei interpretuojama imperializmo teorija ${ }^{25}$.

Ir štai po kelių skyrelių, kuriuose dėstomos ịvairios klasikinio marksizmo koncepcijos, priešpaskutiniame tiesiogiai pereinama prie straipsnio pavadinime suformuluoto klausimo „Kas yra socialdemokratai?"26 ir skyrelyje tokiu pat pavadinimu i ji atsakoma taip: „Socialdemokratai - tai jūs patys draugai darbininkai. Tai tie darbininkai, kurie supratę Markso mokymą, sąmoningai prisidejo prie bendro proletarų laisvès judèjimo; judèjimo, kuris apėmė visų šalių proletarus. Socialdemokratai - tai tie darbininkai, kurie išsirikiavę drąsiai žengia ị kovą su kapitalizmu, kurie žingsnis po žingsnio iškovoja darbininkų klasei daugiau teisių, geresnes gyvenimo sąlygas, o visai žmonijai naują ir teisingesnę tvarką... Darbininkų klasei tenka eiti sunkiu, erškèčiais nuklotu keliu, kol ji pasieks savo tikslo, kol perlauž buržuazijos atkaklumą; bet jai visuomet paguoda tebūna sąmonè, kad proletariatas kovoja ne tik dèl savo laisvès, bet ir dèl ateities visų kartų laimès, geresnio gyvenimo“27.

Paskutinis šio straipsnio skyrelis vadinasi „Ko socialdemokratai reikalauja?“. Čia vèlgi pirmiausia paminima, kad „proletarų“, taip pat ir socialdemokratų tikslas „suvienijus visus darbininkus, visus kapitalo naudojamus, stiprion revoliucinèn darbininkų partijon... nuversti kapitalizmą ir iškovot šviesesnę ateitị, socialistinę visuomenę“. Tačiau čia pat atkreipiamas dèmesys, kad „siekdami šio prakilnaus tikslo socialdemokratai neužmiršta ir artimiausių darbininkų ir darbininkių reikalų“, nes, „kad darbininkai galètų atiduoti daugiau energijos, aukot daugiau jègų kovai dèl socializmo reikalinga visų pirma palengvint jų darbas, sudaryt sąlygas, kuriomis kova dèl naujo, geresnio pasaulio būtų galima“. Taip pat atkreipiamas dèmesys, kad socialde-

25 Žr. pvz.: Самарская, Е. Социал-демократия в начале века. Москва, 1994.

${ }^{26}$ [Kairys S. ?] Kas yra socialdemokratai ir ko jie nori? Socialdemokratas. 1920, gegužès 6, Nr. 4, p. 3-4.

27 Ten pat, p. 4. 
mokratai „reikalauja konfiskuoti privatinių savininkų, dvarų, vienuolynų ir t. t. žemes ir perduot ị valstybės ir savivaldybės rankas“.

Toliau straipsnyje „Kas yra socialdemokratai ir ko jie nori ?“ dar kartą akcentuojama, kad socialdemokratai yra „darbininkų klasės partija“ ir todèl jie „visų pirma rūpinasi palengvinti darbo ir gyvenimo sąlygas fabrikų, gamyklų ir dirbtuvių darbininkams, bernams, mergoms, tarnams ir visiems samdiniams“.

Straipsnis baigiamas šūkiais: „šalin kapitalistinè visuomenè!“ bei „tegyvuoja kova dèl socializmo!“

Tokia socialdemokratijos ir socialdemokratų partijos samprata, kaip 1920 m. straipsnyje „Kas yra socialdemokratai ir ko jie nori?“, neturètų stebinti. Ji visiškai koreliuoja ne tik su kitais XX a. pirmųjų dešimtmečių lietuvių socialdemokratų spaudoje ar brošiūromis publikuotais panašiais tekstais ${ }^{28}$, bet ir su to meto Lietuvos socialdemokratu partijos programomis - $1896 \mathrm{~m}$. LSDP programa ir jos vèlesnèmis (naujomis) 1897 m., 1905, 1907 m., 1919 m. redakcijomis $^{29}$. Visose jose iš pradžių dėstoma marksistinè visuomenès raidos analizè ir iš jos išplaukiančios klasikinès marksistinès kapitalo ir pramonės koncentracijos, visuomenès proletarizacijos, klasių kovos, socialistinès visuomenès neišvengiamumo, proletariato istorinès misijos, istorinio vaidmens pereinant iš kapitalizmo ị socializmą koncepcijos.

Tai patvirtina, kaip ligtolinėse LSDP programose (skirtingų redakcijų) buvo formuluojami šios partijos uždaviniai. Štai $1896 \mathrm{~m}$. LSDP programoje „užduotis lietuviškos socijal-demokratiškos partijos“ formuluojama taip: „paskubinti ir suorganizuoti luominę (klasinę - G. M.) kovą Lietuvos proletariato, kaip ekonomiškoje, taip ir

${ }_{28}$ Žr. pvz.: Ko nori socialdemokratai? Kova, 1907, Nr. 4-47; S. M. [Matulaitis S.] Ko nori socialdemokratai? Moskva, 1918.

29 Žr. pvz.: Programas Lietuviškos Social-demokratiškos Partijos, Tilžè, 1896; Lietuvos Socialdemokratų Partijos programa, b. v., 1905; Lietuvos socialdemokratų partijos programa, LCVA, f. 394, ap.1, b.456. 1. 36-30. 
politiškoje jos dalyje, nurodyti galutinius siekius tos kovos ir pereiginius josios laipsnius..." ${ }^{\text {"30 }}$

Kaip žinoma, po šios formuluotès 1896 m. LSDP programoje buvo pateikiama to meto lietuvių socialdemokratų ideologinei savivokai itin būdinga LSDP „minimumo programos“ ìvadiné formuluoté, kuri baigiasi Lietuvos nacionalinio išsivadavimo siekio formulavimu: „Idant kuo veikiausiai susiorganizuoti ir prisirengti prie užvedimo socialistiško surèdymo, idant užtikrinti darbininkų luomui kuo didžiausią gerovę ir kuo plačiausią politišką liuosybę šioje pereiginèje gadyneje, lietuviška socialdemokratiška partija, pasiremdama ant augščiaus paduotų pamatų (teorinès programos, išdèstytos pirmuose trijuose skyreliuose - G. M.) stato sekanti programą minimum: savystovi demokratiška respublika, susidedanti iš Lietuvos, Lenkijos ir kitų šalių, paremta ant liuosos federacijos "31. Šioje formuluoteje ne tik fiksuojama Lietuvos valstybingumo programa (šio klausimo straipsnyje neaptarsime - jo objektas ne tas, be to, ir istoriografijoje jis daug nagrinètas), bet ir siekis išlaisvinti darbininkų klasę „pereiginèje gadynejje“ ir "prisirengti prie užvedimo socialistiško surèdymo“.

Iš esmès analogiškai, tik dabartinių lietuvių ausiai ịprasčiau formuluojamas socialdemokratų partijos uždavinys vèlesnèse $1896 \mathrm{~m}$. LSDP programos redakcijose ${ }^{32}$. Pavyzdžiui, 1919 m. LSDP programos redakcijoje (t. y. toje LSDP programoje, su kuria ši partija 1919 m. rudenị buvo oficialiai užregistruota Vidaus reikalų ministerijoje - legaliai veiklai Lietuvos Respublikoje) partijos uždavinys apibrèžiamas taip: „organizuoti ir greitinti klasių kovą Lietuvos proletarų, tiek ekonomijos, tiek ir politikos žvilgsniu, rodyti galūtinąji tos kovos tikslą ir pereinamuosius jos laipsnius - yra Lietuvos socialdemokratų partijos uždavinys “33.

\footnotetext{
${ }^{30}$ Programas Lietuviškos Social-demokratiškos Partijos, Tilžè, 1896, p. 8.

31 Ten pat, p. 8-9.

32 Žr. pvz.: Lietuvos Socialdemokratu Partijos programa, b. v., 1905, p. 8-9.

33 Lietuvos socialdemokratų partijos programa, LCVA, f. 394, ap.1, b. 456, 1. 34.
} 
Po šios formuluotès, kaip ir 1896 m. programoje, pateikiama LSDP „programos minimum“ įvadinè formuluotè: „Idant kuoveikiausiai susiorganizuotų ir prisirengtų prie socializmo tvarkos ịkūnimo, idant užtikrinti darbininkų klasei kuo didžiausią gerovę ir kuo plačiausią politikos laisvę šiuo pereinamuoju laiku, Lietuvos socialdemokratų partija, remdamasi ant aukščiau paduotųjų pamatų stato ši programą minimum: ..."

Toliau sekè romėniškas punktas „I su „pamatinių respublikos ìstatymų“ išdèstymu su ịvadine formuluote „Demokratinė Lietuvos respublika. Lietuvos valstybès santykius su kitomis šalimis L.S.D.P. nustato federacijos pamatais“" ${ }^{\text {"34. }}$.

Pažymètina, kad 1919 m. LSDP programos redakcijos priede "Taktikos pamatai“ randame ir formuluotę (iš esmès tokia pat, išskyrus keletą neesminių lietuvių kalbos skirtumų, pateikiama ir atitinkamame $1905 \mathrm{~m}$. programos priede, ir šiek tiek kitaip suformuluota 1896 m. LSDP programos priede ${ }^{35}$ ), kad LSDP kaip „partiné darbininkų klasès organizacija, stengiasi kuo plačiausia sujudinti minią“ ir "tam tikslui šiandien jos varoma agitacija, remiama ekonominiais ir politiniais proletariato reikalais ir tam tikslui išnaudojami esti visi svarbesni mūsų gyvenimo atsitikimai norint parodyti, kad darbininkų gerovei yra du svarbiausiu priešu - kapitalistai ir jų vyriausybë“36.

Toliau ką tik cituotame Lietuvos socialdemokratų programos priede buvo sakoma, kad LSDP „varo agitaciją raštu ir gyvu žodžiu, jau dabar organizuodama darbininkų minias ir keldama kovą su darbininkų eksploatatoriais - kapitalistais ir jų vyriausybe“ (1905 m. programos redakcijoje buvo „kapitalistais ir caro valdžia“) ir „keldama“ šią „kovą“ LSDP „mano, kad vien tik suvienytos darbininkų pajègos

34 Ten pat.

35 Lietuvos Socialdemokratu Partijos programa, b. v., 1905, p. 13-14; Programas Lietuviškos Social-demokratiškos Partijos, Tilžè, 1896, p. 13.

${ }^{36}$ Lietuvos socialdemokratų partijos programa, LCVA, f. 394, ap. 1, b. 456, 1. 30. 
tegalès paimti viršų kovoje proletariato su jo išnaudotojais“ ir kad „tik darbininkai, supratę klasinès kovos - ekonominès ir politinès svarbumą, tegali būti reguliari proletarų armija“" 37 .

Taigi ir iš 1919 m., ir iš ankstesnių Lietuvos socialdemokratų partijos programos redakcijų ryškẻja labai aiški LSDP kaip darbininkų klasès, kaip proletariato partijos savivoka. Ne veltui 1919 m. LSDP iregistravimo dokumente oficialiai - legaliai veiklai Lietuvos Respublikoje nurodyta, kad šios partijos tikslas yra ,jungti darbininkus ir kovoti už jų teises ir pagerinimą jų gyvenimo kaip socialiniai taip ir ekonominiai“"38.

Panašiai kaip $1896 \mathrm{~m}$. programoje ir vėlesnèse jos redakcijose LSDP uždavinys apibūdintas ir naujoje, $1921 \mathrm{~m}$. priimtoje LSDP „Veikimo programoje“. Vienas iš pagrindinių jos autorių, kaip pagrindinis partijos ideologas, buvo S. Kairys.

Pagal $1921 \mathrm{~m}$. gana radikalios interpretacijos marksistinès visuomenès raidos analize pagrịstą "Veikimo programą“ LSDP uždavinys buvo „padèti Lietuvos darbininkams suprasti savo klasès reikalus ir uždavinius“, t. y. padèti darbininkams „virsti sąmoningais socialistais, padèt jiems susiorganizuoti ir paimti politinę valdžią í savo rankas, padèti jiems pasiruošti vykinti socialistinę tvarką visose gyvenimo srityse“ ir kad tam „geriausis ir tikriausis kovos būdas - ... masių veikimas“, „kūrimas visame krašte masinių darbininkų organizacijų, kurios savo veikimo pamatan dètų revoliucinès klasių kovos dèsnius “39.

Reikia pastebėti, kad „Veikimo programą“ prièmusios $1921 \mathrm{~m}$. vasario 26-28 d. vykusios LSDP konferencijos nutarime „Einamojo momento ịvertinimas“ „einamasis momentas“ buvo „ivertintas, kaipo ...

37 Ten pat. L. 30. Plg.: Lietuvos Socialdemokratu Partijos programa, b. v., 1905, p. 13. Platesnị LSDP programos 1919 m. redakcijos aptarimą žr.: Mitrulevičius, G. Lietuvos socialdemokratijos ideologiné-politiné raida 1914-1919 metais... p. 725-733.

38 Žinios apie Lietuvos socialdemokratų partiją, LCVA, f. 394, ap. 1, b. 456, 1. 40., 25.

39 Lietuvos S.-D. Partijos Konferencijos nutarimai (Vasario 26-28 d.1921 m.). Kaunas, 1921, p. 8-9. 
gadynè ... socialistinès revoliucijos“, kurios „pamatinị turinị sudaro proletariato kova su kapitalistinès visuomenės gynėjais už socializmo santvarkos igyvendinimą “40.

Antro minimos konferencijos nutarimo „Artimiausi Partijos uždaviniai“ pradžioje teigiama, kad „Lietuva, neišvengiamos būtinybès verčiama eis ta ịvykių vaga, kurią sudarys pasaulinio proletariato kova su kapitalistine dabarties visuomene ir tvarka“ ir „Lietuvos darbininkai gaus paskelbti Lietuvoje tą didžiulę kovą ir atlikti kuriamąji darbą, kuriuos vykdys kiekvienos šalies proletarai pas save namie“41.

Tačiau antro nutarimo antroje pastraipoje konstatuojama, kad „Lietuvos ūkis ir visuomenès tvarka yra žymiai atsilikę nuo kitų šalių“, be to, „Lietuva liko ypatingai sugriauta karo metu“, tad ant „Lietuvos darbininkų pečių gula dvigubai sunkus uždavinys“.

Kaip LSDP uždaviniai „šiuo metu“ čia buvo nurodyta: „Lietuvos darbininkų klasinès sąmonès gilinimas; darbininkų politinių ir profesinių organizacijų plètojimas ir stiprinimas“, „dedant tam darbui visų galimų pastangų“; išnaudojimas, vedant kovą už darbininkų klasès reikalus, tam tikslui visų „buržuazinès-demokratinės respublikos tvarkos“ tam teikiamų galimybių, „auklëjimas darbininkų sąmoningais savo siekimų kovotojais“; „telkimas prie savęs visų revoliucinių krašto jègų“, „stovinčių ant klasių kovos pamato“, su „kuriomis bus galima susiprasti““,; „gyvų ryšių tarp Lietuvos organizuotų darbinin$\mathrm{ku}$ ir socialistinio Europos proletariato palaikymas derinant bendros kovos žygius“ ir „ypatingas ryšių stiprinimas su organizuotais Latvių, Estų ir Suomių darbininkais“42.

Tokia radikali retorika būdinga $1921 \mathrm{~m}$. Lietuvos socialdemokratų uždavinių formulavimui. Toks ar panašus tonas būdingas daugeliui to meto „Socialdemokrato“ vedamųjų ir kitų straipsnių ${ }^{43}$.

${ }^{40}$ Ten pat, p. 22.

41 Ten pat, p. 23.

42 Ten pat, p. 23-24.

43 Žr. : Socialdemokratas. 1920-1921. 
Viena iš konceptualesnių socialdemokratų partijos sampratų pateikiama 1922 m. sausio 19 d. LSDP laikraštyje „Socialdemokratas“ straipsnyje „Kas tai yra partija ir ko ji reikalauja ir savo nario“, pasirašytame pseudonimu „K-is“ (straipsnio autorystè vèlgi greičiausiai priklauso S. Kairiui) ${ }^{44}$.

Šiame straipsnyje rašoma, kad „kiekvienos klasės priešakiniai žmonès privalo: 1) gerai suprasti savo klasès reikalus; 2) teisingai nustatyti savo klasès siekimus, prie kurių klasė turi eiti; 3) tinkamai nustatyti kelius, kuriais eidama klase gali lengviausiai pasiekti savo reikalų apgynimo; 4) suburti ir surišti ị organizaciją, ị partiją, kiek galima daugiau savo klasės žmonių ir 5) nuolatos tai organizacijai vadovauti, kad ji veiktų suderintai ir energingai ${ }^{\text {“45 }}$. Kai visa tai, anot straipsnio autoriaus, „klasė pasiekia“, tada, „galima pasakyti, kad ji jau sukūrè savo partiją“. Partija, - rašoma toliau, privalo turèti „tris pamatinius daiktus: turèti programą (ko partija siekia); nustatyti savo taktiką, arba kelius savam programui igyvendinti ir turèti savo veiklią organizaciją“. Kol nèra „šių trijų pamatinių“ dalykų (programos, taktikos, organizacijos - G. M.), tol, anot straipsnio autoriaus, „nèra pačios partijos“.

Toliau straipsnyje rašoma, kad „kiekvienos partijos uždavinys“ yra „stropiai ginti savo klasės reikalus“, nes partija - „tai yra nelyginant veikiamoji klasés armija, jos geriausi batalionai, kurie nuolatai stovi visuose kovos frontuose ir nuolat tą kovą veda“. Ivairios partijos isstaigos yra „tų batalionų štabai, kurie kovą paruošia ir jai vadovauja“. Kova, kaip minèta, „eina visose gyvenimo srityse“. I jos lauką patenka kiekvienas su klasès interesais („reikalais“) susijęs klausimas.

Pati partijos kova, rašoma minėtame straipsnyje, „yra visų pirma politinè kova ir karščiausia ji verda ten, kur susimeta politinis krašto gyvenimas - krašto seime, vietos savivaldybėse, o per atstovų rinkimus ir šiaip svarbiausiais atsitikimais - pačioj visuomenejj“. Todèl

${ }^{44} \mathrm{~K}$-is [Kairys S.] Kas tai yra partija ir ko ji reikalauja iš savo nario, Socialdemokratas. 1922, sausio 19, Nr. 3 (103), p. 1-2.

45 Ten pat, p. 1. 
politinè kova traktuotina kaip „pirmutinis kiekvienos partijos uždavinys“. Tačiau ne vienintelis: „gerai veikianti partija turi ginti visus savo klasès reikalus“. Partija, pasak nagrinėjamo straipsnio, turi vadovauti ekonominei kovai, rūpintis švietimu, kelti savo „klasės susipratimą“, „drūtinti“ jos organizacijas. Kitaip sakant, politinė partija turi būti „dvasiniu savo klasès vadovu“.

Patys partijos nariai „turi būti labai darbštūs ir pasišventę ir turi veikti labai suderintai kiekvienu atsitikimu“ bei „remtis vienodais partiniais įsitikinimais“. Tad „niekas negali patapti sąmoningu partijos nariu, pirma nepasiruošęs, gerai sau neišsiaiškinęs partijos programos ir taktikos“.

Teoriškai išaiškinus marksistinę partijų kaip tam tikrų klasių interesams atstovaujančių grupių sampratą, aptariamame straipsnyje pereinama prie Lietuvos darbininkų klasės, darbininkų judejimo politinio-partinio atstovavimo problematikos. Čia buvo konstatuota, kad Lietuvos darbininkų judejjimas yra susiskaldęs, kad yra „tartum, neviena darbininkų partija, bet kelios“ ir apskritai darbininkų judèjimas Lietuvoje „susimete į dvi pamatini srovi“. Vieną iš šių „srovių“ sudaro tie, kurie dar „tebèra įsitvėrę kunigų skverno“, o kiti - kurie „dedasi prie klasinio, socialistinio judejimo“. Pirmieji, t. y. tie, kurie „seka ant klerikalų pavadžio“ ir „šliejasi prie Darbo Federacijos“ (politinè darbininkų organizacija, artima Lietuvos krikščionių demokratų partijai, iš esmés jai satelitinè - G. M.), kuri „ne tiek kovoja už darbininkų reikalus, kiek ubagauja ... ieškodami geradarių ir mielaširdingų užtarejjų“. Jie „nepasitiki savimi, nes dar nesupranta savo klasés padèties ir nemato kelio, kuriuo reikia eiti“. Jie vadinami „darbininkų klasės klajūnais, kurie anksčiau ar vèliau susipras ir įsilies ị didžiąją socialistinio judèjimo vagą“. "Susipratusių“ darbininkų pareiga yra „padèti savo sumulkintiems draugams greičiau pasivaduoti iš klerikalų apynasrio“.

Toliau apžvelgiamame straipsnyje rašoma apie socialistinę darbininkų judejjimo srovę, kuri „mūsų laikais“ Lietuvoje, kaip ir užsienyje, 
yra susiskaldžiusi ị atskiras partijas - socialdemokratus, komunistus bei tarp jų „besiblaškančius“ revoliucinius socialistus liaudininkus ${ }^{46}$. Taigi matome, kad 1922 m. pradžioje Lietuvos socialdemokratai komunistus dar kartais vadindavo socialistinio judejimo srove. (Vèliau, kaip žinoma, jie komunistų, komunistinio judejjimo nelaikè socialistinio judejimo srove, o laikè atskiru nuo socializmo komunistiniu judejjimu - G. M.)

Anot aptariamo straipsnio autoriaus, visos socialistinès partijos turi vieną tikslą - „perdaryti visuomenę socializmo pamatais“, bet „jos nesutinka dèl kelių, kuriais reikia eiti prie socializmo“, jos „nesutinka savo taktika“47. Straipsnyje (kaip ir daugelyje kitų publikuotų „Socialdemokrate“ straipsnių) kritiškai vertinama „praejusios revoliucijos metu atsiradusi komunistų partija“, kuri „iš pradžių „paviliojusi“ darbininkus „gražiais pažadais“, buvo „žymiai išaugusi“, tačiau „dabar“ (t. y. 1922 m. pradžioje - G. M.) komunistai „susmuko“, nes „dèl pragaištingų savo žygių nebeteko darbininkų pasitikejjimo“48. Atkreipiamas dėmesys, kad LSDP yra „seniausia darbininkų partija Lietuvoje“, ịsikūrusi daugiau kaip prieš 25 metus ir „daug padejusi darbininkų klasei jos kovoje už savo reikalus“. Čia pat akcentuojamas būtinumas Lietuvos darbininkams „uoliai šviestis ir dètis ị Lietuvos Socialdemokratų Partijos organizacijas“, kad būtų galima „sèkmingiau ir lengviau atsispirti savo priešams“ ir "greičiau pasiekti galutiną savo ir visos žmonijos tikslą - socializmo igyvendinimą" 49 .

Taigi iš paskutinès apžvelgto teksto citatos matome, kad socialdemokratų partijos tikslas yra „socializmo igyvendinimas“. O iš viso apžvelgto straipsnio akivaizdus marksistinis socialdemokratų, kaip darbininkų klasės partijos, pagrindimas.

\footnotetext{
${ }^{46}$ Ten pat, p. 1-2.

47 Ten pat, p. 2.

${ }^{48}$ Ten pat, p. $1-2$.

49 Ten pat.
} 
Be abejo, tokia Lietuvos socialdemokratų ideologinè savivoka buvo būdinga ne tik cituotiems tekstams ir daugeliui kitų „Socialdemokrato" straipsnių ${ }^{50}$. Ji gerai atsispindejo ir jų atstovų kalbose Steigiamajame bei kituose tarpukario Lietuvos parlamentinio laikotarpio Seimuose - I, II ir III ${ }^{51}$. Anot istorikès Danutès Blažytès-Baužienès, rašiusios apie II Seimo darbą, „socialdemokratai nuolatos pabrèždavo savo reikalavimų klasinị pobūdị “52. Pasak minètos istorikès, „socialdemokratai, tvirtai laikydamiesi savo klasinès nuostatos, rengiant socialinius santykius reguliuojančius ịstatymus teikẻ daugybę pasiūlymų, turëjusių gerokai pagerinti šios visuomenès dalies (darbininkų - G. M.) padètị, tačiau retai atsižvelgè ị realias galimybes" ${ }^{\text {"53 }}$.

Beje, naudodami minètą retoriką (kai kurių šiuolaikinių istorikų ne visai pagrịstai vadinamą „bolševikmečio retorika" ${ }^{54}$ ) ir tuo metu, $\mathrm{XX}$ a. 3-iojo dešimtmečio pradžioje, kaltindami valdžią profsąjungų bei apskritai darbininkų judejimo varžymu, kritikuodami dẻl darbininkų judejjimo veikèjų (tiesa, dažnai susijusių su pogrindiniu komunistiniu judejjimu) suėmimų ir suimtųjų mušimo ${ }^{55}$, socialdemokratai iš krikščionių demokratų gana dažnai sulaukdavo kaltinimų, kad gina komunistus, kad už jų stovi ar jiems diriguoja Maskva, kad esą už socialdemokratų , pečių slepiasi priešinga mūsų nepriklausomybei bolševikų akcija"56. Tačiau socialdemokratai tokius kaltinimus griežtai

${ }^{50}$ Kaip vieną iš charakteringų šiuo požiūriu straipsnių žr.: Politinės partijos. Socialdemokratas. 1923, kovo 8, Nr. 10 (162), p. 1-2.

${ }^{51}$ Mitrulevičius, G. Socialdemokratai Lietuvos Respublikos Seimuose 1920-1927, p. 63-102.

52 Blažytė-Baužienè, D. II Seimas, Lietuvos Respublikos Seimu I (1922-1923), II (1923-1926), III (1926-1927), IV (1936-1940) narių biografinis žodynas. Vilnius, 2007 , p. 83.

${ }^{53}$ Ten pat, p. 108.

${ }^{54}$ Bauža, C. Socialdemokratijos ir komunizmo priešprieša Lietuvoje. Socialine demokratija Lietuvoje: LSDP ištakos ir raida. Vilnius, 1996, p. 14.

55 Žr.: Mitrulevičius, G. Socialdemokratų santykis su Lietuvos Respublikos demokratizacijos procesu Steigiamojo Seimo darbo metu 1920-1922 m., p. 105-117.

${ }^{56}$ Žr.: Dèl mūsų reakcijos žygių. Socialdemokratas. 1921, gegužès 26, Nr. 21, p. 1; Steigiamasis Seimas. Socialdemokratas. 1921, gegužès 26, Nr. 21, p. 3. 
atmesdavo tiek Steigiamojo Seimo posèdžiuose, tiek „Socialdemokrato" puslapiuose.

S. Kairys ir kiti po 1919 m. pradžios LSDP krizès socialdemokratijos ideologinei tradicijai likę ištikimi Lietuvos socialdemokratai neigiamai vertino rusiškąji bolševizmą. Jie ne tik vadovaudamiesi marksistine socializmo teorija ir doktrina laikèsi nuostatos, kad Rusija nepribrendusi socializmui, bet ir neigiamai vertino rusiškąjt bolševizmą-komunizmą dèl 1918-1919 m. įvykių Lietuvoje, dèl demokratijos atmetimo ir socializmo kūrimo antidemokratiniais metodais, dèl represijų ir teroro Rusijoje, ypač prieš socialistines šios šalies partijas ir jų narius ${ }^{57}$. Lietuvos socialdemokratai smerkè Rusijos bolševikus ir dèl „socialistinès Gruzijos okupacijos“, dèl trukdymo lietuviams karo pabėgèliams grižti iš Rusijos į Lietuvą ${ }^{58}$.

Lietuvos socialdemokratai neigiamai vertino ir Lietuvos komunistų veiklą už „labai klaidingą ir darbininkams nepriimtiną taktiką“, skatinančią „daryti dirbtines revoliucijas“, „stumiančią darbininkų judejimą i klaidingus kelius“, prie „neapgalvotų žingsnių“, „darbininkų vienybès ardymo“, „darbininkų jègų išeikvojimo ir suskaldymo“, prie „davimo progos“ Lietuvos valdžiai slopinti ir net „,terorizuoti Lietuvos darbininkų judejimą “"59. Socialdemokratai akcentavo, kad taip komunistai aklai eina „talkon valdžiai ir žvalgybai“, padeda „buožèms“ ir dešiniesiems „gniaužti darbininkų organizacijas“ bei „pasmaugti darbininkų profesines sąjungas“.

Anot XX a. 3-iojo dešimtmečio pradžios Lietuvos socialdemokratų, komunistai „skaudžiai pakenkẻ darbininkų judèjimui Lietuvoje“, nes būtent dèl jų „taktikos“ yra „silpnos, apmirusios,

57 Plačiau žr.: Mitrulevičius, G. Lietuvos socialdemokratų požiūris ị rusiškajị komunizmą 1919-1922 metais. Gairés. 2006, Nr. 5, p. 31-36; Nr. 6, p. 25-31.

${ }^{58}$ Ten pat. Taip pat žr.: Mitrulevičius, G. Apie socialdemokratinę Gruzijos Respubliką, bolševikinès Rusijos įvykdytą jos užpuolimą ir užgrobimą $1921 \mathrm{~m}$. bei istorinių Lietuvos socialdemokratų požiūrị ị visa tai. Prieiga per internetą: // www.lsds.lt

59 Apie socialdemokratų požiūrị ị Lietuvos komunistų veiklą žr.: Mitrulevičius, G. Socialdemokratai Lietuvos Respublikos Seimuose 1920-1927, p. 76-77. 
išblaškytos“ Lietuvoje profsąjungos, o darbininkai „tebestovi nesuorganizuoti, pakrikę, nepajègiantys ginti savo reikalų“ ir „negalintys atsispirti prieš kunigų ir visokių išnaudotojų puolimą“. Taip pat apžvelgiamo meto Lietuvos socialdemokratai kaltino lietuvių komunistus ir dèl šmeižtų bei paskalų, dèl „begėdiškos demagogijos“ - „dèl tos šmeižto ir melo taktikos, kurios laikèsi komunistai savo spaudoj ir agitacijoj prieš Lietuvos Socialdemokratų Partiją“, dèl „dervos pylimo ant socialdemokratų“, dèl ,kibirais liejamų pamazgų ant socialdemokratų“ komunistinèje literatūroje, dèl „vienos Lietuvos darbininkų dalies siundymo ant kitos“ bei nuolatinio ,,žegnojimosi žiūrint ị Maskvą“60.

Dèl to socialdemokratai komunistus vadino savo priešais iš kairès. Anot LSDP laikraščio redakcijos, socialdemokratai ,yra ir bus komunistų priešais“61. Dèl to, kaip pabrèžiama $1921 \mathrm{~m}$. birželio $23 \mathrm{~d}$. S. Kairio pasirašytame LSDP CK laiške JAV lietuviams socialistams, „,idejjinè kova su komunistais, su jų taktika darosi socialdemokratams vienas iš svarbiausiųjų uždavinių “62.

Tačiau socialdemokratai pabrèžè, kad jie „kovoja su komunistais ... tik „,idejjiniai“ ir „kovoja su jų pažiūromis“, stengdamiesi „,tikinti Lietuvos darbininkus, kad komunistai klysta..." Todèl LSDP nepritarè valdžios vykdomam kovos su komunistais būdui - „,sodinimui jų i kalèjimus, teismų jų karo teismuose, taikymą jiems mirties bausmės“. Anot socialdemokratų, „Lietuvoje, jei ji nori būti demokratingai sutvarkytas kraštas, visiems turi būti duota liuosai dèstyti savo pažiūras" ${ }^{\text {“63. }}$.

60 Ten pat.

${ }^{61}$ Nuo „Socialdemokrato“ redakcijos. Ar suprantame vienas kitą? Atviras laiškas ị Naumiesčio profsajungų darbininkus. Socialdemokratas. 1921, birželio 30, Nr. 26, p. 2-3.

${ }^{62}$ LSDP CK 1921 VI 23 d. laiškas JAV lietuviams darbininkams-socialistams, LCVA, f. 937 , ap. 1, b. 3, 1. 50 .

${ }^{63}$ Nuo ,Socialdemokrato“ redakcijos. Ar suprantame vienas kitą? Atviras laiškas ị Naumiesčio profsajungų darbininkus. Socialdemokratas. 1921, birželio 30, Nr. 26, p. 2-3. 
Vis dèlto turint mintyje LKP santykị su šalies valstybingumu bei Sovietų Rusija, jos tuometinès veiklos ypatumus, matyt, galima teigti, kad pasisakydami iš esmès tik už idejjinę kovą prieš komunistus socialdemokratai ar bent nemaža jų dalis ne visada adekvačiai vertino komunistų veiklą. Tačiau tokia jų pozicija nuosekliai išsirutuliojo iš pasisakymo už besąlygišką "gryną“ demokratiją. I pastarąji aspektą dar atkreipsime dèmesí. Čia baigdami glaustai aptarti Lietuvos socialdemokratų nuostatas rusiškojo komunizmo bei Lietuvos komunistų atžvilgiu galime apibendrinti, kad iš esmés jos panašios išliko visą parlamentinès demokratinès Lietuvos laikotarpí.

Taigi remdamiesi tuo, kas šiame straipsnyje išdèstyta, galime teigti, kad aptariamo laikotarpio (XX a. 3-iojo dešimtmečio pradžios) LSDP politinę ideologiją galètume apibūdinti kaip prorevoliucinị, palyginus radikalų marksistinị, bet antikomunistinị (antibolševikinị) socializmą.

\section{Tarpukario Lietuvos socialdemokratai kaip radikalūs demokratiniai marksistiniai socialistai}

Prieš tai buvusio skyrelio pabaigoje apibūdinome straipsnyje apžvelgiamo laikotarpio LSDP santyki su rusiškuoju bolševizmu ir Lietuvos komunistais. Turẻdami mintyje ši santykị, taip pat aptartą XX a. 2-ojo dešimtmečio pabaigos - 3-iojo dešimtmečio pradžios S. Kairio ir visos LSDP požiūrị i tai, kas apskritai yra (turi būti) socialdemokratų partija bei atsižvelgdami ị čia plačiau neaptartas (tam reikètų gerokai platesnio straipsnio) to meto LSDP ir apskritai socialdemokratijos bendrąsias ideologines programines nuostatas, to meto LSDP ideologiją galètume apibūdinti ne tik kaip gana radikalų socialdemokratinị socializmą, bet ir kaip prorevoliucinị (tačiau ne bolševikine-komunistine žodžio „revoliucinis“ prasme) bei kartu ir radikaliai demokratinị socializmą. 
Prorevoliuciškai socialistines ir radikaliai demokratines (taigi ir antibolševikines) aptariamo meto Lietuvos socialdemokratų nuostatas rodo ir 1920 m. birželio 23 d. Steigiamajame Seime perskaityta S. Kairio socialdemokratų frakcijos deklaracija ${ }^{64}$ ir šios frakcijos bei apskritai LSDP nuostatos 1922 m. priimant nuolatinę Lietuvos Respublikos konstituciją ${ }^{65}$, apskritai partijos frakcijos ir atskirų jos narių politinè laikysena. Tai, beje, liudija ir $1921 \mathrm{~m}$. vasario konferencijos nutarimas „Internacionalo klausimas“, kuriame konstatuojama, kad III internacionalas „yra padaras Rusijos revoliucijos“, kuri šiuo laikotarpiu negali nuvesti Rusijos „prie socializmo“, ir tai motyvavus ir nurodžius, kad III internacionalas „negalejjo sutelkti platesnių revoliucinio proletariato minių“, atkreipiamas dėmesys, kad „ne jam teks spręsti ir griežtąją kovą su imperializmu“ ir kad to „sprendimo“ reikia laukti iš Vakarų industrinių valstybių, „kur jau esama ekonominių sąlygų socialistinès revoliucijos ir kur gali įvykti galutinoji kova už socializmą" ${ }^{\text {"66 }}$.

1921 m. LSDP konferencijos požiūriu, "galutinąją kovą tarp darbo ir kapitalo“ „tepajègs pakelti“ tik „naujas Internacionalas, sutraukęs i savo eiles visų tų kraštų (Vakarų industrinių kraštų - G. M.) socialistinị ir revoliucinị proletariatą“. Mat $1921 \mathrm{~m}$. LSDP požiūriu, ir II internacionalas, „kurio sudètyje yra oportunistinių organizacijų“, „tam reikalui neatsako“. Todèl LSDP konferencija „skaitė reikalingu remti revoliucinès socialdemokratijos pastangas sudaryti aktingą, revoliucinị ir pajėgų Internacionalą didiems tarptautinio proletariato

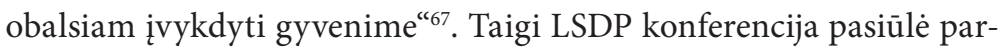

${ }_{64}$ Žr.: St. Seimo socialdemokratu frakcijos deklaracija, Kaunas, 1920; Socialdemokratai Lietuvos Respublikos Seimuose, Vilnius, 2006, p. 677-682.

65 Žr.: Mitrulevičius, G. Radikaliai demokratinès respublikos vizija: Steigiamojo Seimo socialdemokratų frakcijos nuostatos priimant $1920 \mathrm{~m}$. laikinają ir $1922 \mathrm{~m}$. nuolatinę Lietuvos Respublikos Konstitucijas, p. 706-740; Mitrulevičius, G. Socialdemokratai 1922 metų Lietuvos Respublikos Konstitucijos prièmimo procese (1920-1922 m.), Gairès, 2007, Nr.: 7, p. 32-39; Nr.: 8, p. 26-35.

${ }^{66}$ Lietuvos S.-D. Partijos Konferencijos nutarimai (Vasario 26-28d. 1921 m.).p. 26.

${ }^{67}$ Ten pat, p. 27. 
tijai „remti“ vadinamąji II 1/2 [antrąji su puse] internacionalą, sukurtą $1921 \mathrm{~m}$. pradžioje Vienoje socialdemokratų partijų, besivadinančių „revoliucinio socializmo“ šalininkèmis ir atsiribojusių tiek nuo bolševizmo (komunizmo), tiek, anot šių „revoliucinių socialistų“, ir nuo „oportunistų iš II-ojo Internacionalo“68.

LSDP konferencijoje išreikštą poziciją liudija ir patvirtina ir partijos laikraštyje „Socialdemokratas“ paskelbtas pranešimas apie minètą tarptautinę socialdemokratų partijų konferenciją Vienoje ${ }^{69}$. Čia buvo rašoma, kad „naująji Internacionalą“, kuris „be abejo susikurs“, sudarys „tos partijos, kurios skaito, kad dabar pasaulyje eina socialistinè revoliucija“, kurios „dedasi ị kovą už darbininkų siekimus ir nepripažịsta jokio bičiuliavimosi su buržuazija“, tačiau kurios „iš kitos pusés skaito, kad komunistai klaidingai suprato tuos kelius, kuriais eis pasaulio revoliucija, kad komunistai stveriasi netikusių kovos būdų ir kad jie - komunistai - dèl to patys žlugdo darbininkų judejjimą" "70. LSDP laikraštyje atkreipiamas dėmesys, kad „naujojo Internacionalo branduolị sudarys galingos anglų, prancūzų, vokiečių, šveicarų ir rusų darbininkų partijos (turima omenyje Rusijos socialdemokrataimenševikai - G. M)“ bei prie kuriamo naujojo internacionalo prisidès „ir kitų šalių proletariato organizacijos"“71.

Taigi dar kartą turime pažymèti kad XX a. trečiojo dešimtmečio pradžios Lietuvos socialdemokratai buvo gana radikalūs socialistai, galima sakyti, net vieni radikaliausių to meto Europoje socialdemokratų. Ne veltui jiems, kaip ir minètoms vadinamąji „II 1/2 Internacionalą" sukūrusioms socialdemokratų partijoms, buvo nepriimtinas nemažai Vakarų socialdemokratinių partijų vienijęs atkurtas II internacionalas. Vertinant pagal laikmečio aplinkybes, tokios to meto

${ }^{68}$ Braunthal, J. Geschichte der Internacionale Bd.2., 2Aufl., Berlin, Bonn, 1978, s. 249-254.

${ }^{69}$ Vienos konferencija. Socialdemokratas. 1921, kovo 3, Nr. 9, p. 3.

${ }^{70}$ Ten pat.

${ }^{71}$ Ten pat. 
lietuvių socialdemokratų bendrosios ideologinės nuostatos visiškai suprantamos ir paaiškinamos. 1925 m. S. Kairys straipsnyje „Partijos programos reikalu“ rašè, kad tuo metu, kai $1921 \mathrm{~m}$. susirinko LSDP konferencija, Lietuvos socialdemokratai „jautèsi stovi jei ne pačioj iškilusios proletarų revoliucijos viršūneje, tai bent gyvam jos sūkury“ ir „buvo pilni vilties, kad laikinai suslūgusi revoliucijos banga vèl iškils dar galingesnè ir duos galimybès pasauliniam proletariatui imtis socializmo tvarką vykdinti"72. To meto socialdemokratų nuomone, jei „socializmas įsigyvendins kur kitur, jis turès issikurti ir Lietuvoje“.

Tokio ịsitikinimo, anot minèto 1925 m. S. Kairio straipsnio, buvo „kiaurai pažymèta“ $1921 \mathrm{~m}$. LSDP „Veikimo programa“. Dèl to ji ir buvusi pavadinta „veikimo programa“, tai yra, tokia, „kuri turi nustatyti partijos darbuotès pagrindus pereinamajam tarpui nuo esamos kapitalistinès tvarkos prie socialistinès“ ir dèl to jos „teoretinejj programos daly maža rūpintasi duoti pilną kapitalistinio ūkio apibūdinimą“ bei „plačiai kalbama dèl „paskutinio“ kapitalistinès visuomenès tarpo ir dar plačiau dèl uždavinių, kuriuos darbininkų klasė gaus toj fazèj vykinti“. Patys „programos reikalavimai išdèstyti praktiškoj jos daly“, pasak S. Kairio straipsnio „Partijos programos reikalu“, „liko suformuluoti jaučiant galingą vykstančios revoliucijos alsavimą ir prie jo prisitaikant“.

Tačiau, anot S. Kairio, praejjus keletui metų tapo aišku, kad socialistinè revoliucija pasaulyje dar nevyksta ir kelerių metų patirtis verčia permąstyti ir iš naujo suformuluoti kai kurias programines nuostatas. Svarstydamas, kurias konkrečiai reikètų permąstyti ir pakeisti, S. Kairys, šalia kritiško pasisakymo dèl nuostatos $1921 \mathrm{~m}$. LSDP „Veikimo programoje“ esą „pasaulyje vykstančios socialistinès revoliucijos“, suabejojo (beje, remdamasis Karlu Kautskiu) ir dèl tuo

${ }^{72}$ Kairys, S. Partijos programos reikalu. Socialdemokratas. 1925, balandžio 9, Nr. 15 (277), p. 2. 
metu minètoje partijos programoje buvusių nuostatų už „tarybų sistemą“ ir „proletarų diktatūrą“" adekvatumo ir reikalingumo ${ }^{73}$.

Taigi glaustai apžvelgę $1925 \mathrm{~m}$. paskelbtą S. Kairio straipsnị galime daryti išvadą, kad tuo metu Lietuvos socialdemokratams jau nebebuvo būdingas toks prorevoliucinis radikalizmas kaip 3-iojo dešimtmečio pradžioje. Panašiai evoliucionavo ir kitos kairiosios Europos šalių socialdemokratų partijos. Paminėtina, kad dar $1922 \mathrm{~m}$. pasireiškè vadinamojo „II 1/2 Internacionalo“ suartejjimas su II internacionalu, $1923 \mathrm{~m}$. pasibaigęs abiejų šių socialistinių internacionalų susijungimu ị vieningą Socialistų internacionalą ${ }^{74}$, kuriam, beje, nuo pat pradžių priklausè ir LSDP.

Taigi galbūt galima kelti klausimą, kad ir Lietuvos socialdemokratams atsakant ị klausimą „kas yra socialdemokratų partija“ 3 -iojo dešimtmečio pradžioje, galejo turèti įtakos cituotame S. Kairio 1925 m. straipsnyje minètas „einamojo meto“ vertinimo kontekstas.

Tikètina, partijos uždavinių formuluočių radikalumą lèmè ir S. Kairio minèta „laikmečio dvasios“ socialdemokratiškoji samprata. Tačiau, kita vertus, vertinant laikmečio situaciją, Lietuvos socialdemokratų ideologinių nuostatų radikalumas neišnyko, tik sumažėjo. Antai 1925 m. XII LSDP suvažiavime S. Kairys apie to meto Europos situaciją kalbejjo, kad „buržuazija siekia taikos tik dèl to kad greičiau

${ }^{73}$ Kairys, S. Partijos programos reikalu. Socialdemokratas. 1925, balandžio 16, Nr. 16 (278), p. 1. Proletariato diktatūros sąvokos supratimas ir interpretavimas neįeina ị šio straipsnio objektą, tad čia tik galime pacituoti, kad, pagal $1921 \mathrm{~m}$. LSDP „Veikimo programą““, „Proletarų diktatūra reiškia daugumos viešpatavimą ant mažumos. Darbininkų klasė Lietuvoje tuomet tegalès imti ị savo rankas politinę krašto valdžią ir ịgyvendinti socializmo tvarką, kai visuomenès ūkio išsivystymas pas mus pastatys ị proletarų eiles arba su jais suriš mūsų visuomenès daugumą, kuomet ta dauguma virs sąmoninga socializmo tvarkos šalininke“. Žr.: Lietuvos S.-D. Partijos Konferencijos nutarimai (Vasario 26-28d. 1921 m.), p. 8. Tai, anot istoriko Č. Baužos, reiškè, kad „LSDP programoje ,proletariato diktatūra“ reiške ne ką kitą, kaip „,proletarizuoto“ "krašto darbininkų daugumos pergalę demokratiniuose rinkimuose". Žr.: Bauža, Č. Min. veik., p. 14.

${ }^{74}$ Plačiau apie II $1 / 2$ bei II internacionalų tarpusavio santykius bei SDI ịkūrimą žr.: Braunthal, J. Min. veik., s. 258-272, 284-291. 
atsistatydintų kapitalistinis ūkis“, kad ji „vèl galètų pelnytis ir lobti“, kad ji su „visu įnirtumu puola darbininkų klasę“, „puola ekonominius darbininkų laimèjimus ${ }^{\text {"75. }}$.

Cituojamoje programineje S. Kairio kalboje teigiama, kad „revoliucijos metais Europos proletariatas išplètè savo politines teises ir ne viename krašte bandè paimti valdžią i savo rankas“ ir kad „atsigavusi buržuazija kur tik gali atsiima valdžią iš darbininkų“ ir „kur darbininkus nuveikia sudaro reakcijos režimą, siaurina darbininkų laisves, varžo ir bando gniužinti darbininkų judejjimą“ ir kad „aštri politinè kova tarp darbininkų ir esamos tvarkos šalininkų eina visu Europos frontu“, ir kad „Europos socialistinis proletariatas ne tik sekmingai atmuša buržuazijos puolimus, bet visoj eilejj kraštų jau yra paėmęs politinę valdžią ir stiprinasi dar atkaklesnei kovai" ${ }^{\text {"76 }}$.

Cituojamame pranešime, be abejo, nepamirštama atkreipti dèmesị, kad „kovodami dèl dienos reikalų, darbininkų klasẻ nepaleidžia iš akių galutinio savo tikslo, - igyvendinti socializmą“ ir kad „tas darbininkų uždavinys iš idealo pradeda virsti praktišku siekimu, vis gyviau žadina socialistinę mintị, vis giliau sujudina ir ịtraukia kovon plačiąsias minias“, kad dèl to „Europos socialistinis proletariatas praktiškai ruošiasi prie socialistinès kūrybos "“77.

Matydami tokias bendrąsias ideologines nuostatas bei to meto europinès situacijos vertinimą, neturètume stebètis, kad principinis marksistinis socialdemokratų kaip socialistinès darbininkų klasės partijos, siekiančios sukurti socializmą kaip santvarką, supratimas išliko ir vèliau. Tai liudija tiek vèlesni S. Kairio tekstai apie tai, „kas yra socialdemokratų partija“, tiek $1931 \mathrm{~m}$. LSDP programos projektas.

Pavyzdžiui, XX a. 3-iojo dešimtmečio pirmosios pusès straipsnyje „Kas yra socialdemokratų partija?“ S. Kairys rašè: „Trumpai sakant Socialdemokratų partija yra Lietuvos darbo žmonių partija... Social-

${ }^{75}$ [Kairys S.] Partijos uždaviniai einamuoju momentu, Budrys, D. L. S. D. Partijos XII-asis Suvažiavimas. Kaunas, 1925, p. 23.

${ }^{76}$ Ten pat.

${ }^{77}$ Ten pat, p. 24. 
demokratų draugijon šiandien dedasi žmonès, kurie patys gyvena iš savo rankų darbo, kurie vienodai supranta dabartinę gyvenimo tvarką ir vienodai tiki kad ta tvarka turi būti permainyta nauju teisingu socialistiniu gyvenimo surèdymu“78.

Straipsnyje teigiama, kad socialdemokratai „ne tik tiki nauju žmonijos gyvenimu, bet ir kovoja su dabarties neteisybèmis už ateities laimę. Socialdemokratai mato, kad pats gyvenimas ruošia kelią socialistinei ateičiai, bet jie taip pat supranta, kad be žmonių rankų be jų pasiryžimo naujas gyvenimas nesusikurs. Už naują gyvenimą gali kovoti tik tie žmonès kurie nepakenčia mūsų gadynès neteisybių, kuriems šiandien yra nepakeliamai bloga, kurie naujoj tvarkoj mato savo vargų galą“. Tokiais žmonėmis socialdemokratai skaito visus rankų ir proto darbininkus, vis vien kur jie dirbtų ir ką jie dirbtų. Kiekvienas kuris savo gyvasties išlaikymui yra verčiamas pardavinèti savo darbą, kas už nepakeliamą triūsą mato tik nepakeliamą vargą, skriaudas ir paniekinimus, visi tie socialdemokratų supratimu gali ir turi būti socializmo kovotojais ${ }^{\text {“79. }}$.

Socialdemokratai kaip aiškūs kovotojai už socializmą suvokiami ir „pusiau priimtoje ${ }^{\text {"80 }} 1931 \mathrm{~m}$. LSDP programoje (programos projekte) ${ }^{81}$. Ši LSDP programa, parašyta S. Kairio ir A. Žvirono, gerokai platesnè nei ankstesnès. Pirmojoje, teorineje, dalyje „duodama palyginti plati“ marksistine visuomenès procesų analize paremta „žmonijos istorijos apžvalga“, aptariamos „kapitalistinès santvarkos ydos, analizuojamas kapitalistinio ūkio plitimas Lietuvoje, klasių kova, darbininkų siekių internacionalumas, pereinamasis laikotarpis iš kapitalistinės santvarkos ị socialistinę ${ }^{\text {" } 82}$.

${ }^{78}$ [S. Kairys] Kas yra Socialdemokratų partija? LMAB, RS, f. 12-285, 1. 171.

79 Ten pat, 1. 171-172.

80 Žr.: Mitrulevičius, G. Lietuvos socialdemokratai po III Seimo paleidimo 1927-1940, p. 218-219.

81 Žr.: Lietuvos socialdemokratų partijos programa, Kairys, S. Tau, Lietuva. Boston, 1964, p. 420-452.

82 Plačiau apie šią programą žr.: Krivickas, V. Min. veik., p. 105-109; Lukoševičius, V. Min. veik., p. 270-278. 
Pateikiama ir aiški socialdemokratų kaip klasinès darbininkų partijos, vedančios kovą prieš kapitalistinę visuomenès santvarką, samprata. Pavyzdžiui $1931 \mathrm{~m}$. LSDP programoje rašoma, kad „... kapitalistinès santvarkos ydos sukèlé prieš ją darbininkų klasę - tuos milijonus, kurie kurdami pasaulio turtus, patys yra bado, skurdo, tamsumo, ir smurto kankinamos aukos“ ir dèl to „iškilo esamosios neteisingos santvarkos smerkejjai - socialistai“, kurie „ne tik įrodè kuo kapitalistinè santvarka yra bloga, bet taip pat ịrodè, kad kapitalistiné visuomenès santvarka pati rengia sau galą, kartu rengdama pagrindus naujai socialistinei visuomenei ${ }^{\text {“83. }}$.

Toliau sakoma: „socialdemokratai parodè darbininkų klasei kelią, kuriuo ji turi eiti, kad išsivaduotu iš kapitalo vergijos ir kartu sukurdama naują socialistinę santvarką, ịvestų visą žmoniją i̇ naują šviesų gyvenimą ${ }^{\text {“84 }}$.

$1931 \mathrm{~m}$. LSDP programos projekte taip pat pabrěžiama, kad „socialdemokratija vadovaudama darbininkų klasės kovai jos uždavinị kelia visu platumu. Ir todèl kiekvienas kuris stoja ị socialdemokratijos eiles, turi būti įsitikinęs socialistas ${ }^{\text {(855 }}$.

$1931 \mathrm{~m}$. LSDP programos projektas buvo paskutinis tarpukariu tokio pobūdžio LSDP programinis dokumentas. Šis lietuviškos socialdemokratijos programinis dokumentas, kurio pagrindinis autorius S. Kairys, aiškiai rodo socialdemokratų kaip aiškių socialistų, fizinio ir protinio darbo darbininkų klasès partijos, supratimą. Šituo požiūriu Lietuvos socialdemokratai išliko nuoseklūs visą tarpukarị.

Aptariamu laikotarpiu aršus S. Kairio ir jo vadovaujamos LSDP oponentas Lietuvos krikščionių demokratų lyderis Mykolas Krupavičius po Antrojo pasaulinio karo rašè, kad „LSDP buvo marksistinë“, o ,jos lyderis Kairys ne be reikalo jų frakcijos narių Čepinskio

${ }^{83}$ Lietuvos socialdemokratų partijos programa, Kairys, S. Tau, Lietuva. Boston, 1964, p. 422

${ }^{84}$ Ten pat, p. 422-423.

${ }^{85}$ Ten pat, p. 430. 
ir Povyliaus buvo vadinamas marksizmo rabinu" ${ }^{\text {"86 }}$. Anot M. Krupavičiaus, „labai jautrus savo socialdemokratiškajai skaistybei“ S. Kairys „bendrai saugojo, kad partija neiškryptų iš marksizmo ribų "87. Tad tokia iki šiol aptarta S. Kairiui ir tarpukario LSDP būdinga socialdemokratijos samprata neturètų stebinti. Tuo metu ji buvo natūrali. Pats socialdemokratijos tapsmas, išejimas ị istorijos areną buvo sąlygotas socializmo teorijų ir darbininkų judejimo susijungimo $^{88}$. Minètas K. Kautskis, XIX a. pab. - XX a. pr. autoritetingiausias vokiečių socialdemokratijos ideologas, socializmo bei II internacionalo teoretikas, $1891 \mathrm{~m}$. oficialiai Vokietijos socialdemokratų partijos (VSDP) užsakytos knygos $1891 \mathrm{~m}$. VSDP Erfurto programos teorinei daliai paaiškinti (iki $1914 \mathrm{~m}$. ji buvo išversta i 18 Europos kalbų ir tapo savotišku to meto "socializmo katekizmu“ ${ }^{89}$ ) autorius, rašè, kad „socialdemokratija yra socializmas plius darbininkų judejimas " 90 .

Atkreiptinas dèmesys, kad šiame straipsnyje buvo pateikta socialdemokratijos samprata, išplaukusi iš daugelio šalių socialdemokratų partijų programų. Jos variantai XIX a. pabaigoje - XX a. pirmojoje pusejje buvo déstomi socialdemokratijos teoretikų bei ideologų, pirmiausia K. Kautskio tekstuose. Pirmiausia, žinoma, paminètina VSDP $1891 \mathrm{~m}$. Erfurto programa, parašyta K. Kautskio ir Eduardo Bernšteino. Anot marksizmo tyrinètojo A. Walickio,

${ }^{86}$ Krupavičius, M. Visuomeniniai klausimai. Chicago, 1983, p. 45.

87 Ten pat.

${ }^{88}$ Mitrulevičius, G. Lietuvos socialdemokratijos ideologiné-politiné raida 1914-1919 metais..., p. 165-166.

89 Walicki, A. Marksizmas ir šuolis $j$ laisvès karalystę. Komunizmo utopijos istorija. Vilnius, 2005, р. 258.; Андреуччи, Ф. Распостранение и популяризация марксизма, История марксизма Т. 2, Пер. с итал. яз., Москва, 1981.; Кретинин, С В. Карл Каутский (1854-1938): Опыт переосмысления, Новая и новейшая история, $1995 \mathrm{Nr}$ 1, с. 148.: Пристланд, Д. Красный флаг. История коммунизма, Москва, 2011, с. 104-105.

90 Каутский, К. Эрфуртская программа. Коментарий к принципиальной части. Пер. с немец. яз., Москва, 1959, с. 218. 
tai ne tik „pirmoji sąmoningai marksistinè partine programa“, kurios „svarbą papildomai didino faktas kad ją perskaite ir aprobavo F. Engels“, bet ir buvusi „daugeli metų ịtakingiausiu tarptautinio darbininkų judèjimo dokumentu“91. Pasak Wernerio Sombarto, „šią programą galima prilyginti tikejjimo simboliui, kokị paliko M. Lutheris savo pasekejjams" ${ }^{\text {"92 }}$.

Erfurto programos teorinè dalis - tai koncentruota marksistinè visuomenès raidos, visuomenės procesų analizè, parašyta K. Kautskio remiantis K. Markso „Kapitalo“ 24 skyriaus 7 poskyryje (paragrafe) išdèstytomis pramonès ir kapitalo koncentracijos, visuomenės proletarizacijos, proletariato skurdimo, ekonominių krizių, kapitalizmo kaip paskutinès išnaudotojiškos santvarkos, klasių kovos visuomenės socializacijos bei proletariato išvaduojamosios misijos koncepcijomis, kurios (ar bent kai kurios iš jų) buvo išdèstytos dar „Komunistų Partijos Manifeste ${ }^{\text {“93 }}$.

$1891 \mathrm{~m}$. Erfurto programa, kaip politiškai ịtakingiausios socialdemokratinès partijos programa, kaip ir jos teorinei daliai paaiškinti ir išaiškinti skirta oficialiai VSDP užsakyta ir K. Kautskio parašyta knyga - cituoti Erfurto programos komentarai - turejo didelę įtaką Vidurio ir Rytų, Pietryčių ir Šiaurès Europos šalių socialistinių partijų programoms ir šių šalių socialistinio judejjimo ideologijai ${ }^{94} 1896 \mathrm{~m}$. LSDP programa, kaip parodè specialus istoriko

91 Walicki, A. Min. veik., p. 258.

92 Зомбарт, В. Социиализм и социальное движение. Санкт Петербург, 1908, с. 186.

93 Žr.: Programatische Dokumente der deutschen Sozialdemokratie, Bonn, 1990, s. 185-189. Lietuviškai Erfurto programa išversta ir publikuota V. Merkio straipsnyje apie pirmujų LSDP programų kilmę. Žr.: Merkys, V. Lietuvių SDP pirmujų programų kilmè, Lietuvos TSR Mokslu akademijos darbai, serija A 3 (22), 1966, p. 140-141. Erfurto programos palyginimui su „Komunistų partijos Manifestu“ bei „Kapitalu“ žr.: Marksas, K. ir Engelsas, F. Komunistu partijos Manifestas, Vilnius, 1988.; Marksas, K. Kapitalas. T. 1. Vilnius, 1957, p. 679-681.

94 Apie Erfurto programos įtaką žr.: Кривогуз, Й. Второй Интернационал (18891914), Москва, 1964, с. 63, 72. Savo socialistinių partijų istorinès raidos tyrime S. Bartolinis, pristatydamas Europos socialistinių partijų ankstyvojo raidos etapo 
Vytauto Merkio atliktas jos „kilmès“ tyrimas, taip pat buvo parengta remiantis pirmiausia $1891 \mathrm{~m}$. Erfurto programa ${ }^{95}$. S. Kairys atsiminimuose rašè, kad $1896 \mathrm{~m}$. LSDP programos teorinis pagrindimas buvo „grynai marksistinis, toks, koks buvo pas vokiečių ar austrų socialdemokratus ${ }^{\text {" }}$.

Kitos XX a. pradžios LSDP programos redakcijos (1897 m., 1905 m., 1907 m., 1919 m.) teorinejje dalyje atkartojo tai, kas buvo dèstoma 1896 m. programoje. Kaip ir 1925 m. VSDP Haidelbergo progra$\mathrm{mą} \mathrm{iš} \mathrm{dalies} \mathrm{neformaliai} \mathrm{galime} \mathrm{vadinti} 1891 \mathrm{~m}$. Erfurto programos redakcija. 1921 m. LSDP „Veikimo programoje“ jaučiamos, kaip minejome, daliai socialdemokratijos tuo metu būdingos radikalejjimo tendencijos. Galbūt iš dalies tai tik mažesniu laipsniu galima pasakyti ir apie 1920 m. S. Kairiui priskiriamą straipsnị „Kas yra socialdemokratai ir ko jie nori ?"

Atkreipus dèmesi i tai, kad dauguma to meto socialdemokratų vadovavosi marksizmu, nereikètų pamiršti, kad aptariamu istoriniu laikotarpiu ne tik vyko „ginčas dèl marksizmo“ ir „ginčas dèl socializmo" ${ }^{\text {"97 }}$ tarp socialdemokratų ir Rusijos bolševikų-sovietinių komunistų, bet socialdemokratijai teko susidurti ir su rusiškojo bolševizmo pergalès Rusijoje pagimdyto XX a. komunizmo iššūkiu ir aršiu

ideologines orientacijas, išskiria „ortodoksinị revoliucinị marksizmą“, būdingą Vokietijos, Austrijos ir Suomijos socialistinèms partijoms, ir ,neortodoksinị nuosaikų marksizmą“, būdingą Danijos, Švedijos, Belgijos, Nyderlandų, Norvegijos ir Šveicarijos socialistinėms partijoms. Žr. Bartolini, S. The Political Mobilization of the European Left 1860-1980, p. 408. Pastebėtina, kad kitas autorius (K. Vössingas), pradinị socialdemokratinių partijų istorijos laikotarpi tyrinėjęs iš politikos mokslo pozicijų, marksizmu besivadovavusias partijas traktavo kaip „kvazirevoliucines“ partijas, skirtingai nuo evoliucinių Jungtinès Karalystès, Australijos ir Naujosios Zelandijos leiboristų partijų. Žr. Vössing, K. The formation of social democratic parties. Degrees of inclusion as external constraints and the strategic choices of labor elites // Paper prepared for the Comparative Politics Research Workshop (CPRW), 2008, p. 46 // http://polisci.osu.edu/intranet/cprw/papers/vossing.pdf.

95 Merkys, V. Min. veik., p. 138-151.

96 Kairys, S. Lietuva budo. Boston, 1964, p. 275.

97 Žr. pvz.: Meyer, T. Sozialismus, Wiesbaden, 2008, s. 50-92. 
jo puolimu jos atžvilgiu, apie ką iš dalies, apžvelgdami Lietuvos atvejị, straipsnyje užsiminème.

Kaip žinome, didžiąją dalị tarpukario komunizmas socialdemokratiją laikė didžiausiu priešu. Komunistai kaltino socialdemokratus darbininkų judejjimo, marksizmo, apskritai socializmo išdavimu bei tarnavimu buržuazijai, imperializmui, buvimu „buržuazijos agentūra darbininkų judèjime" ir t. t. XX a. 3-iąjị dešimtmetị bei 4-ojo dešimtmečio pirmojoje pusejje komunistai socialdemokratiją traktavo kaip „socialfašizmą“, „kairịji fašizmo sparną“, pavojingesnị už atvirą fašizmą ${ }^{98}$. O socialdemokratai komunistus, kaip straipsnyje buvo minèta, kaltino nuo socializmo neatsiejamos demokratijos atmetimu, socializmo ir marksizmo sampratų iškraipymu, ne darbininkų klasės viešpatavimo, o diktatūros darbininkų atžvilgiu ivedimu, taip pat teroristinès ir imperialistinès politikos vykdymu ${ }^{99}$. Dalis socialdemokratų jau tarpukariu ir komunizmą, ir fašizmą traktavo kaip totalitarinius judejimus ir laikè didžiausiais socializmo priešais.

Straipsnyje rekonstruota S. Kairiui ir istorinei LSDP būdinga socialdemokratijos samprata akivaizdžiai rodo, kad to meto socialdemokratai neatsisakè nei vadovavimosi marksizmu, nei socializmo kaip santvarkos siekimo, nei identifikavimosi kaip darbininkų klasès partija, tad minèti komunistų kaltinimai akivaizdžiai demagoginiai.

Tarpukario Lietuvos socialdemokratams būdingos socialdemokratijos sampratos analizė tik patvirtina, kad jie tuo metu, kaip ir kitų šalių socialdemokratai (tai yra, pirmų dviejų socialdemokra-

98 Sovietinio komunizmo požiūris ị socialdemokratiją pristatytas: Mitrulevičius, G. Lietuvos socialdemokratijos ideologiné-politiné raida 1914-1919 metais..., p. 54-87.

99 Plačiau apie tai žr.: Mitrulevičius, G. Ar buvo SSRS socializmas: socialdemokratų ir kitų kairiujų požiūriai istoriniu aspektu. Gairès, 2007, Nr. 9, p. 31-38, Nr. 10, p. 35-43.Taip pat. žr.: Zarusky, J. Die deutschen Sozialdemokraten und das sowjetische Modell. Miunchen, 1992. 
tijos istorinès raidos etapų socialdemokratų partijos), save suvokè kaip už socializmą kovojančią darbininkų partiją, kaip „Arbeiterklassenpartei“. Tai akivaizdžiai buvo parodyta šiame straipsnyje. Taip pat atlikta analizè tik patvirtina teiginị, kad dauguma antrojo etapo, kaip ir nemažai pirmojo etapo socialdemokratų partijų, vadovavosi marksistinio socializmo doktrina (skirtingai nuo trečiojo, juolab ketvirtojo istorinès raidos etapų socialdemokratų).

Apskritai galima teigti, kad straipsnyje pristatyta socialdemokratijos (socialdemokratų partijos) samprata (ir radikalesnis, ir nuosaikesnis variantas) yra būdinga pirmajam ir antrajam socialdemokratijos istorinès raidos etapams. Kaip žinoma, skiriami keturi jos etapai: 1) XIX a. pabaigos - XX a. pradžios; 2) tarpukario; 3) vadinamoji klasikinè - XX a. antrosios pusès (šeštojo - devintojo dešimtmečių) ir 4) XX a. pabaigos - XXI a. pradžios „naujoji“ liberali socialdemokratija, pačioje XXI a. pradžioje dažnai vadinta Trečiojo kelio socialdemokratija ${ }^{100}$.

Rekonstruojant ir aiškinantis S. Kairiui ir istorinei (tarpukario) LSDP būdingą socialdemokratijos sampratą, reikia turèti omenyje istorinị jos sąlygotumą. Kitaip sakant, tarptautinị socialdemokratijos ideologinès-politinès raidos kontekstą. Kita vertus, reikia nepamiršti ir kitų tokios socialdemokratijos sampratos istorinio sąlygotumo aspektų, kaip antai tarpukario socialinès ekonominès situacijos bei visuomenès padèties, to, kad Lietuvos socialdemokratams beveik visą tarpukarị, išskyrus trumpą buvimą valdžioje 1926 m., teko patirti mažesnị ar didesnị, net visišką veiklos varžymą.

${ }^{100}$ Žr. pvz.: Die Reformfähigkeit der Sozialdemokratie. Herausforderungen und Bilanz der Regierungspolitik in Westeuropa, hrsg.: Merkel, W. Henkes, Ch., Wiesbaden, 2006, s. 25; Schiller, T. Demokratischer Sozialismus / Sozialdemokratie, Politische Theorien (Lexikon der Politik, Band 1). München, 1995, s. 49-56. 


\section{Išvados}

1. Žvilgsnis i tarpukario LSDP lyderio ir pagrindinio ideologo S. Kairio tekstus ir šio laikotarpio LSDP programas bei jų analizè akivaizdžiai patvirtina, kad to meto Lietuvos, kaip ir daugelio kitų šalių, socialdemokratai save suvokè kaip marksistine visuomenės raidos analize besivadovaujančią darbininkų klasès partiją, siekiančią sukurti socializmą kaip santvarką.

2. Straipsnyje rekonstruota S. Kairiui ir to meto LSDP būdinga socialdemokratijos samprata aiškiai paneigia sovietinio komunizmo ideologijos ir istoriografijos teiginius, kad tarpukariu socialdemokratija atsisakė marksizmo (,išdavė marksizmą“), atsisakè siekti socializmo santvarkos, nustojo būti darbininkų klasès partija.

3. Rekonstruota socialdemokratijos samprata taip pat rodo, kad tarpukariu socialdemokratai, save traktuodami kaip marksizmu besivadovaujančią ir socializmo siekiančią partiją, komunistus laike „,savo priešais“, o „idejjinę kovą“ su jais - „vienu iš svarbesnių savo uždavinių“. İsigilinę ị S. Kairio ir istorinei LSDP būdingą socialdemokratijos sampratą, galètume to meto Lietuvos socialdemokratus laikyti antibolševikiniais marksistiniais socialistais.

4. Kalbant apie straipsnyje aptartą rekonstruotą patiems Lietuvos socialdemokratams būdingą socialdemokratijos sampratą (socialdemokratų ideologinę savivoką), pabrèžtinas jos istorinis sąlygiškumas. Akivaizdu, kad socialdemokratijos samprata (socialdemokratų ideologiné savivoka) buvo veikiama laiko dvasios - XX a. 3-iojo dešimtmečio pradžioje jos retorika buvo gerokai radikalesnè - revoliucingesnè. Vèliau ji tapo nuosaikesnè, tačiau socialdemokratijos esmè dèl to nesikeitè. 


\title{
THE CONCEPT OF SOCIAL DEMOCRACY IN THE INTERWAR LSDP PROGRAMMING DOCUMENTS AND IN THE TEXTS OF THE PARTY LEADER STEPONAS KAIRYS
}

\author{
Gintaras Mitrulevičius
}

\section{Summary}

Keywords: Social Democratic Party, LSDP, Social Democracy, Socialism, Democratic Socialism, Steponas Kairys

Social democracy played an important role in the history of Western Europe in the 20th century. In Lithuania, the social democratic movement played an important role in the Lithuanian national liberation movement from the late 19 th century to the early 20 th century. In interwar Lithuania, during its democratic period (1920-1926), the LSDP was one of the few main parliamentary parties in Lithuania. All this, as well as the occasional motive - in 2019, the 140th anniversary of the birth of Steponas Kairys, the leader and ideologue of the historical Lithuanian Social Democracy, is an important argument for explaining the concept of social democracy in the ideology of the interwar LSDP. That is the object of this article. The aim of the article is to find out and reconstruct how it was answered to the questions "Who are the Social Democrats?", "What is the Social Democratic Party"? in the interwar LSDP programmatic documents and S. Kairys' texts.

After analyzing the LSDP programmatic documents and the texts of the party leader S. Kairys, the following conclu- sions are available: 1) A look at the texts of S. Kairys, the leader and chief ideologue of the interwar period LSDP as well as a look at the programs of this party of this period clearly confirms the statement that the Lithuanian Social Democrats of that time, as in many other countries, the Social Democrats saw themselves as a working-class party based on a Marxist analysis of the development of society, seeking socialism as a social order; 2) The article reconstructs the interwar LSDP programs and The conception of social democracy in Kairys's texts is clearly refuted thesys by Soviet communist ideology and historiography, that interwar social democracy abandoned Marxism, that it "betrayed Marxism", that it allegedly refused to carry out the socialist order, that it ceased to be a working class party; 3 ) The reconstructed concept of social democracy in the article also shows that by treating themselves as a Marxist-led and socialist party of the Social Democrats, the social democrats of the time considered the communists of the time "their enemies", "ideological struggle" with "one of their most impor- 
tant tasks“. Getting acquainted with the concept of social democracy characteristic of S. Kairys and the historical LSDP allows to state that the Lithuanian Social Democrats of that time can be considered
anti-Bolshevik Marxist socialists; 4) With regard to the reconstructed concept of social democracy discussed in the article, the historical conditionality of this concept should be noted.

Iteikta $2020 \mathrm{~m}$. kovo $30 \mathrm{~d}$. 